tische wandeling te wijzen op de rol van vrouwen in de geschiedenis van de stad, maar ook stilstaan bij een aantal historische bezienswaardigheden van Brussel, die door al te weinig mensen naar waarde worden geschat. Deze gids bestaat uit drie delen: een kleine vrouwenwandeling, een grote vrouwenwandeling en een gedeelte met achtergrondteksten, waarin telkens verwijzingen zijn naar sites die in de respectievelijke wandelingen zijn opgenomen. De kleine vrouwenwandeling bestaat uit een volledig uitgestippeld parcours dat start aan de Kleine Zavel en eindigt aan het Groot Begijnhof, met onderweg zevenentwintig haltes. De grote vrouwenwandeling bestaat uit een lijst met suggesties, aangevuld met een woordje uitleg, van interessante sites buiten het stadscentrum. Er wordt telkens aangegeven hoe $\mathbf{u}$ deze sites met het openbaar vervoer kan bereiken. Op het einde van de brochure tenslotte zijn vijf teksten opgenomen die elk afzonderlijk een deel van de Brusselse vrouwengeschiedenis belichten. De teksten behandelen respectievelijk religie en ziekenzorg, prostitutie en vrouwenhandel, beeldende kunsten, arbeid en politiek en feminisme. Op de achterflap vindt $u$ een plattegrond van Brussel-centrum waarop de sites duidelijk zijn gemarkeerd. Nog een pluspunt is de zeer verzorgde, frisse lay-out. Aan u om de wandeling in praktijk om te zetten.

Cherchez la femme. Een wandeling door de geschiedenis van de vrouw in Brussel, Documentatiecentrum Rol \& Samenleving, Brussel, 1999, $160 \mathrm{p}$.

\section{Marcel Kerff, "Kom, we zijn tebie". Bezembinders en scharenslieps. Voyageurs in Vlaanderen}

Piet Creve, Amsab

Toen ik een kleine jongen was, ging ik vaak logeren bij een kinderloze oom en tante in Sint-Amandsberg. Af en toe nam die tante mij mee naar de 'winkels' in het centrum van Gent.

Aan het gemeentehuis van Sint-Amandsberg stapten we op de tram. De wandeling door de winkelstraten begon aan het Belfort. Tussen dit monument en de SintNiklaaskerk stond bij de rand van het trottoir een merkwaardig vehikel: het zag eruit als een kruising tussen een fiets, cen kruiwagen en een marktkraam. "Da's een scharensliep.", zei tante. "Die maakt messen en scharen weer scherp." Ik was uitermate geboeid door wat de man aan het doen was, maar toen ik dichter wou gaan, hield tante me tegen. "Niet zo dicht, "t is een bohemer." Op mijn vraag wat dat was, wou of kon tante geen antwoord geven.

Permanent rondtrekkende mensen hebben in de meeste maatschappijen een kwalijke naam. Het lijkt ook zo absurd, vasthouden aan een nomadische levenswijze als het sedentaire bestaan zoveel meer comfort biedt. En is een vaste stek geen bewijs van een hogere evolutie? Het misprijzen, of in elk geval het wantrou- 
wen tegenover zwervers uit zich ook in de vele namen die ze kregen: bohemers, voyageurs, zigeuners, forains... Marcel Kerff geeft de verschillen kort, maar duidelijk aan en concentreert zich dan op zijn eigenlijke onderwerp, de voyageurs. Dat zijn mensen van bij ons die in de cerste helft van de 19e eeuw overgingen op een nomadische levenswijze als reactie op hongersnoden en epidemieën. Ze trokken in familieverband rond van dorp tot dorp en probeerden tijdelijk werk te vinden op boerderijen en andere plaatsen waar extra mankracht nodig was. Eerst zwierven ze te voet rond, dan kwamen er karren die ze zelf trokken, nog later paarden en woonwagens. Voyageur worden was dus aanvankelijk een overlevingsstrategie in bijzonder barre tijden, net als migreren naar de nieuwe industriële centra van de 19 e eeuw. Maar al snel werd het een aparte levensstijl, een subcultuur die meer en meer aansloot bij die van andere zwervers, zoals de zigeuners.

Het is niet verwonderlijk dat van die kleine groep mensen weinig geschreven bronnen bestaan. Marcel Kerff moest zich hoofdzakelijk behelpen met mondelinge getuigenissen en in mindere mate met foto's. Maar hij haalt uit dit materiaal een schat aan elementen om de diverse aspecten van het leven van de voyageurs weer te geven. De uiteenlopende manieren waarop ze geld verdienen, hun manier van wonen, de problematische scholing van de kinderen, hun beleving van religie en de vaak moeilijke verhouding met de sedentaire maatschappij krijgen vorm in de vele verhalen. Dit boek heeft de verdienste dat het een onbekende en vaak misbegrepen groep voor het voetlicht haalt; niet als een rariteitenkabinet, maar als mensen met herkenbare verwachtingen en teleurstellingen. Terecht merkt de auteur op dat de tijd drong: zoveel getuigen zijn er niet meer, veel voyageurs hebben willens nillens dan toch maar een vaste stek gezocht. Bovendien is hun eigenheid aan het vervagen: het Vlaams Centrum Woonwagenwerk dat in 1997 het Vlaams Overleg Woonwagenwerk opvolgde, richt zich naar alle bewoners van woonwagens. Marcel Kerff brengt zijn boeiend relaas in een publicatie met een aantrekkelijke lay-out. Alleen jammer dat de eindredactie enkele storende foutjes niet opmerkte, zoals de verkeerde schrijfwijze van de Dossin-kazerne in Mechelen van waaruit vele woonwagenbewoners tijdens de Tweede Wereldoorlog op transport werden gezet naar de concentratiekampen. Maar deze gruwelijke ervaring verhinderde niet dat er tot 1975 een officiële zigeunerkaart bleef bestaan.

\author{
M. KERFF, "Kom, we zijn tebie”. \\ Bezembinders en scharenslieps. Voyageurs \\ in Vlaanderen, Leuven: Van Halewyck, 2000
}

